\title{
1. A short history of the arbitral settlement of interstate disputes until the establishment of the PCIJ
}

\section{OVERVIEW OF THE ARBITRAL SETTLEMENT OF INTERSTATE DISPUTES BEFORE THE HAGUE PEACE CONFERENCES}

Time and again in the centuries-old history of interstate relations there have emerged ideas arguing that states have to submit their disputes for third party settlement, especially to adjudication as an alternative to war. Such conceptions can be traced to old legends, according to which disputes between states or sovereigns were settled by arbitration. The records that have come down to us suggest that in more than one case bitter disputes were submitted to arbitration and the majority of arbitral awards were executed by the parties. In other words, it seems that recourse to arbitration was for centuries a rare but successful means of settling interstate disputes.

Arbitration between ancient Greeks was rather widespread. Relying on cases treated by various authors, Taube estimates that over five hundred years, from the 7 th to the middle of the 2 nd century B.C., the number of cases settled by arbitration between the city-states (polis) ran to about $110 .{ }^{1}$ Some sort of arbitration was practised in theory by the Senate between allies (socii) in the Roman Empire, but one cannot speak of genuine arbitration at the time of the Roman Empire as Rome sought to have even the institution of arbitration serve its own expansionist aspirations. ${ }^{2}$ As Nicolas Politis rightly points out 'Rome considered itself

\footnotetext{
1 Cf. Michel de Taube, 'Les origines de l'arbitrage international antiquité et moyen age' in Collected Courses of the Hague Academy of International Law, 1932 (Recueil Sirey 1933) tome 42, IV, 14.

2 On arbitration in the Graeco-Roman word see id., 24-56.
} 
as the arbitrator of the world, accepted to be judge, but not to be justiciable'. ${ }^{3}$

In the Middle Ages, the arbitral settlement of disputes between souvereigns was relatively frequently used and serving as sole arbitrators were, besides the Pope, sovereigns, kings, emperors and, not infrequently, certain institutions, law professors and lawyers acting on their behalf.

By the 18th century, arbitration had practically disappeared from interstate relations, a fact which seems to be strange and incomprehensible, especially because the retreat of arbitration was witnessed precisely in the decades subsequent to the Peace Treaty of Westphalia, even though the foundation of contemporary international law was, in point of fact, laid by that Treaty.

The idea of international arbitration was throughout centuries closely linked to different - rather illusory - projects of federation between states of the 'civilized' world, often with plans for 'perpetual peace' related thereto. ${ }^{4}$ Among the various projects for 'perpetual peace' and the related plans for a federation of European states, the greatest influence was undoubtedly exerted by Abbe Saint-Pierre's work, 'Projet pour rendre paix perpétuelle' (1713). ${ }^{5}$ The influence of Saint-Pierre's plan was

3 '... se considérant comme arbitre du monde, elle acceptait d'être juge, non justiciable'. Nicolas Politis, La Justice Internationale (2nd edn, Librairie Hachette, 1924), 27.

4 Such a conception was formulated in Pierre Dubois's work, 'De recuperatione Terrae Sanctae', probably of 1306, in the proposal of King George of Pogebrady of Bohemia and his advisor (the humanist, Antonio Marini from Geneva) concerning the alliance of Christian States in the second part of the 15th century, and in the perceptions of King Henry IV of France and presumably his Minister Sully about a federation of European States. For more detail, see, Ernst Reibstein, Völkerrecht, eine Geschichte seiner Ideen in Lehre und Praxis (Karl Alber, 1958); and Jacob Ter Meulen, Der Gedanke der Internationalen Organisation in seiner Entwicklung (Martinus Nijhoff 1917) Vol. I, 99-339. One could also mention Émeric Crucé from the 17th century whose work remained practically unknown to later centuries. Émeric Crucé proposed the establishment of a permanent congress composed of representatives from all sovereigns, regulating the differences between them. However, the gravest questions touching sovereignty and independence should be settled by arbitration. According to Crucé, once arbitration was admitted to these disputes, it could not be rejected for disputes of lesser importance. See Émeric Crusé, Le nouveau Cynée (Réimpression du texte original de 1623 avec introduction et traduction anglaise par Thomas Willing Balch, Lane and Scott 1909).

5 Charles Irénée Castel de Saint-Pierre, Projet pour rendre paix perpétuelle (Publisher Chez Antoine Schouten, Marchand Libraire MDCCXIII) (Open Librarie). 
enormous both in his own time and afterwards. ${ }^{6}$ One should also mention the famous perpetual peace project of the great philosopher Immanuel Kant. ${ }^{7}$

In connection with the peace plans of the 17 th and 18th centuries, the French author Michel Revon is right in noting that all these plans share the imperfection of being vague, utopian and having no practical meaning. ${ }^{8}$

A much more realistic view than those of the aforementioned authors is struck by such classics of international law as Grotius and Vattel. By citing historical examples, according to Grotius, wars could be evaded by arbitral decision as well. ${ }^{9}$

6 Cf. Ter Meulen (1932), 180-221. Thus, for example, both Rousseau and Leibnitz dealt extensively with Saint-Pierre's work. See also Jean-Jaques Rousseau, A project for perpetual peace (Thomas Nugent (tr.) M. Cooper 1761). Rousseau's abridgement of Saint-Pierre's work; and Wilhelm Gottfried Leibniz, Observations sur le Projet de paix perpétuelle de l'abbé de Saint-Pierre, précédées de la lettre de Leibniz à l'abbé de Saint-Pierre du 7 février 1715. (Presses universitaires de Caen 1993).

7 Immanuel Kant, Perpetual peace: A Philosophical Sketch (1795), (translated with introduction and notes by Marie Campbell Smith, M.A.; Preface by Professor Latta. (1st edn), George Allen \& Unwin Ltd., The MacMillan Company, 1903) 218. Kant's essay on Perpetual peace takes the form of an international treaty, with the author's comments and an Appendix.

8 Michel Revon, L'arbitrage international: Son passé. - Son présent. - Son avenir (Librairie nouvelle de droit et de jurisprudence 1892) 144.

9 Grotius writes:

The office of deciding wars and putting an end to the contentions of armies was assigned, according to Starbo, to the Druids of the Gauls, and upon the testimony of the same writer, it formed a part of the priestly functions among the Iberians.

Surely then it is a mode of terminating their disputes, balancing their powers, and settling their presentations worthy to be adopted by Christian Kings and States. For if, in order to avoid trials before judges who were strangers to the true religion, the Jews and Christians appointed arbitrators of their own, and it was a practice recommended and enjoined by St. Paul, who much more sought such a practice to be recommended and enforced, to gain the still nobler end of preventing the calamities of war.

These and many other reasons of no less importance might be advanced for recommending to Christian powers general congresses for the adjustment of their various interests, and for compelling the refractory to submit to equitable terms of peace.

Hugo Grotius (Hugo de Groot), On the Law of War and Peace (Tr. from the original latin De Jure Belli ac Pacis and slightly abridged by A.C. Cambell, A.M., Batoche Books 2011) 235. 
Vattel writes that, 'When sovereigns cannot agree about their pretensions and are nevertheless desirous of preserving or restoring peace, they sometimes submit the decision of their disputes to arbitrators chosen by common agreement.' ${ }^{10} \mathrm{He}$ emphasises that, 'Arbitration is a very reasonable mode, and one that is perfectly comfortable to the law of nature, for the decision of every dispute which does not directly interest the safety of the nation.' 11

The great English author, jurist and philosopher Jeremy Bentham in his essay, 'A Plan for an Universal and Perpetual Peace', points very rightly to the advantages of third party settlement by saying that 'Establish a common tribunal, the necessity for war no longer follows from difference of opinion. Just or unjust, the decision of the arbiters will save the credit, the honour of the contending party.' 12

The idea to settle interstate disputes by adjudication was markedly present in the works of writers of the second half of the 19th century, owing not least to the fact that arbitral settlement of disputes between states had become rather frequent during that century and in the last two decades of the century more arbitral awards were rendered than those put together in the first part of the century. ${ }^{13}$ The modern era of arbitration

10 Emmerich de Vattel, The Law of Nations, or the Principles of Natural Law (Tr. from the French by Joseph Chitty, Esq. Based on the 1797 edition, republished by T.\&J.W. Johnson 1853) Book II, § 329.

11 Id.

12 Jeremy Bentham, 'The Principles of International Law' Essay 4, in The Works of Jeremy Bentham (published under the superintendence of his executor, John Bowring, vol. II. William Tait, Simpkin, Marshall \& Co., MDCCCXLIII), 552.

13 The following figures can be mentioned in support of this statement. The number of arbitral awards was

1 between 1801 and 1810

about 17 between 1811 and 1820

about 5 between 1821 and 1830

about 7 between 1831 and 1840

about 7 between 1841 and 1850

about 23 between 1851 and 1860

about 25 between 1861 and 1870

about 28 between 1871 and 1880

about 46 between 1881 and 1890

about 61 between 1891 and 1900

Cf. A.M. Stuyt, Survey of International Arbitrations 1794-1970 (Sijthoff, Oceana 1972) 6-237. 
dates back to the Jay's Treaty of $1794,{ }^{14}$ and later on to the Alabama Arbitration in 1871-72, a successful settlement of a harsh dispute between the United States of America and the United Kingdom arising from the American Civil War. ${ }^{15}$

During the 19th century, there were numerous plans for establishing international tribunals and some authors were arguing not only for such forums but for the introduction of a general obligation of states to recourse to arbitration for the settlement of certain disputes. The most notable among them were plans of Dudley Field (American lawyer and member of the US Congress), ${ }^{16}$ the Moscow professor Kamarowsky, ${ }^{17}$ and Mérignhac from France, who developed similar principles which were adopted later at the First Hague Peace Conference. ${ }^{18}$ Also concerned with projects of a permanent international court of arbitration

14 After the Treaty of Paris (1783), which ended the American War of Independence, the relations between the United States and Great Britain deteriorated. On 19 November 1794, the Treaty of Amity, Commerce, and Navigation (Jay's Treaty) was signed, which among other things, provided for the establishment of three mixed claims commissions for dispute settlement. The first arbitral commission dealt with the delimitation of which river was under the name of St. Croix mentioned in the Treaty of Paris. The second commission's task was to deal with claims with respect to debts owed by American citizens (or residents) to British creditors contracted before the peace. The third commission had to settle the claims of American citizens against Great Britain regarding the illegal seizure of ships and cargos. The mixed commissions consisted of an equal number of members (two or four) appointed by each of the two states, plus an umpire chosen by them or drawn by lot. The mixed commissions decided many claims to the satisfaction of the parties.

15 The Alabama Claims were a series of claims for damages by the United States against Great Britain for the assistance given to the Confederation during the American Civil War and especially for the violation of neutrality by allowing the construction in Britain of the warship Alabama, which caused significant damage to the US Navy and merchant marine. The arbitration tribunal, composed of five arbitrators, decided the case on 14 September 1972.

16 Cf. David Dudley Field, Project d'un Code International: Proposé aux diplomates, aux hommes d'État, et aux jurisconsultes du droit international (Albéric Rolin tr., Pédone-Lauriel, Adolphe Hoste 1881) 880.

17 Cf. Leonide Kamarowsky, Le tribunal international (Serge de Westman (tr.), G. Pedone-Lauriel 1887).

18 According to Mérignhac, one day there will be a permanent international forum whose decisions will be sanctioned by international forces. Cf. Alexandre Mérignhac, Traité théorique et pratique de l'arbitrage international (L. Larose Éditeur 1895) 516. 
were the Universal Peace Congresses, the Interparliamentary Union, the Institut de Droit International and the International Law Association. ${ }^{19}$

A rather clear and - one might safely say - still valid statement about international arbitration during the 1880s was made by the Russian Professor Friedrich Fromhold Martens ${ }^{20}$ to the effect that, regarding the future of international arbitration, it was necessary to distinguish hopes and realities and international arbitration was not the way to go in all international disputes in which the political element was paramount. ${ }^{21}$ In the author's view, international arbitration is a viable path in the case of less significant disputes, particularly concerning questions of a legal nature and in cases where the rights of the parties can be clearly identified. ${ }^{22}$

\section{THE RESULTS OF THE HAGUE PEACE CONFERENCES}

The establishment of an arbitral tribunal was discussed in detail at the First Hague Peace Conference in 1899, convened at the initiative of the Russian Tsar Nicholas II, with the purpose of elaborating on proposals for the reduction of armaments and discussing peace with the object of preventing armed conflicts between nations.

At the First Hague Peace Conference, several proposals regarding arbitration and methods of pacific settlement of interstate disputes were presented, ${ }^{23}$ and the majority of delegates agreed that the settlement of disputes by international arbitration was important and desirable, but the

19 Cf. Dr Hans Wehberg, The Problem of an International Court of Justice (The Clarendon Press 1918) 132-40.

20 Later on F.F. Martens was one of the leading figures of the Hague Peace Conferences in 1899 and 1907.

21 Cf. F. de Martens, Traité de droit international (Alfred Léo (tr.), Librairie Marescq Ainé 1887) vol. 3, 154-5.

22 Id. 155.

23 Draft proposals were submitted by Great Britain, Italy, Russia and the United States. Those drafts drew heavily upon the customary law on arbitration that was available at the end of the 19th century, as well as upon the drafts prepared by the Institut de droit international (see Resolution of the Institut de droit international adopted at the Session of 1875 at The Hague termed, 'Projet de réglement pour la procédure arbitrale international') and the Interparliamentary Union. The starting point for the negotiations was furnished by the Russian and British drafts, which were debated in a so-called special Committee of Examination.

The documents produced by the Russian, British, American and Italian delegations, see The Hague Peace Conferences of 1899 and 1907 and International 
debate was rather sharp about the arbitral tribunal to be established and mainly about whether states were under obligation to submit their disputes to that forum. During the negotiations, concrete proposals on obligatory arbitration were formulated in certain cases, ${ }^{24}$ provided that neither the vital interests nor the national honour of states were affected. Recourse to arbitration in other matters was to be subject exclusively to the discretion of states, and the parties' consent to such recourse was to be required in each case. ${ }^{25}$

The negotiations produced a draft proposing the introduction of compulsory international arbitration in a number of cases. ${ }^{26}$

Arbitration. Reports and Documents. (Compiled and edited by Shabtai Rosenne, T.M.C. Asser Press 2001) 89-113.

24 It was the Russian proposal that went furthest towards the introduction of obligatory arbitration.

25 According to the Russian draft, subject to obligatory arbitration would be all legal matters which, arising in disputes between states, did not affect the vital interests and the national honour of states. The Russian draft specified two classes of international disputes subject to obligatory arbitration, notably pecuniary claims to recover for unlawful injuries on the one hand and, on the other, the interpretation or application of certain non-political conventions, chiefly treaties known as 'universal unions' like the one exemplified by the Treaty of 1874 on the Universal Postal Union, which in Art. 16 provides obligatory arbitration for the solution of all differences concerning the interpretation or application of that treaty. Cf. Rosenne (2001) 47.

26 Under the terms of the draft,

Arbitration is obligatory between the high contracting Powers in the following cases, so far as they do not concern the vital interest or national honour of the States in controversy:

I. In case of disputes concerning the interpretation or application of the conventions enumerated herein:

(1) Postal, telephone, and telegraphic conventions.

(2) Conventions concerning the protection of submarine cables.

(3) Conventions concerning railroads.

(4) Conventions and regulations concerning means of preventing collisions of vessels at sea.

(5) Conventions concerning the protection of literary and artistic works.

(6) Conventions concerning the protection of industrial property (patents, trade-marks, and trade-names).

(7) Conventions concerning the system of weights and measures.

(8) Conventions concerning reciprocal free assistance to the indigent sick.

(9) Sanitary conventions, conventions concerning epizooty, phylloxera and other similar scourges.

(10) Conventions concerning civil procedure. 
The draft appeared to be acceptable to the majority of delegates, but upon the second reading the German delegate came out against the adoption of the text, as in the German Government's view the experience to date was not sufficient to support the introduction of compulsory arbitration in connection with the conventions enumerated in the draft. According to the German delegation, 'a too rapid introduction of obligatory arbitration into international law might present more dangers than advantages from the point of view of peace among nations. ${ }^{27}$ Thereupon the Russian delegate submitted another draft proposing the introduction of compulsory adjudication in a still smaller number of questions. However, the delegates were still unable to reach an agreement and in place of enumerating various conventions, they adopted an article containing a twofold provision. The first refers to treaties which already provide a resort to arbitration, the second one is a declaration reserving the right to conclude new agreements extending obligatory arbitration to cases which they deem possible of submission thereto. ${ }^{28}$

The result of the negotiations was a text which later on appeared as Articles 15-19 in the Convention for the Pacific Settlement of International Disputes. That was a compromised text, reflecting the principle of voluntary arbitration, postulating that each State decides in its sovereign capacity whether a dispute should be submitted to arbitration or not. However, in Article 19 there was a reference to treaties stipulating obligatory arbitration, providing that the contracting parties may conclude new agreements with a view to extending arbitration to other cases they consider suitable for arbitration.

At the First Hague Peace Conference, regarding the establishment of an arbitral tribunal, the outcome was also a compromised solution, although a permanent machinery was adopted and an agreement was reached on the establishment of the Permanent Court of Arbitration. ${ }^{29}$ What was not a real court but a list of jurists, designated up to four judges by each contracting party to the 1899 Convention for the Pacific

(11) Extradition conventions.

(12) Conventions for delimiting boundaries so far as they touch upon purely technical and non-political questions.

II. In case of disputes concerning pecuniary claims arising for damages when the principle of indemnity is recognized by the Parties.

27 Report to the Conference from the Third Commission on Pacific Settlement of International Disputes. See Rosenne (2001) 48.

28 Id. 48.

29 On the Permanent Court of Arbitration and on cases decided by it see, James Brown Scott (ed.) The Hague Court Reports (OUP 1916) cxi, 664. 
Settlement of International Disputes, from among whom, in concrete disputes, the members of each arbitral tribunal might be chosen. Nevertheless, one can say that with the establishment of the Permanent Court of Arbitration, international tribunals have become a constant institution of international law, and the judicial settlement of international disputes is no longer a sporadic phenomenon in interstate relations. Thus, one can agree with Hershey that 'its importance lay rather in what it held out by way of promise for the future than of actual achievement' ${ }^{30}$

At the Second Hague Peace Conference in 1907, the question of obligatory arbitration and the conclusion of a convention on that subject were lengthily discussed. Several proposals were submitted by delegates with respect to the class of disputes to be subject to obligatory arbitration and regarding the revision of the 1899 Convention for the Pacific Settlement of International Disputes in this respect. ${ }^{31}$ The Conference nevertheless reached no agreement on matters that were to be subject to obligatory arbitration without reserve nor the creation of a permanent tribunal, finally very few amendments were adopted to the provisions on international arbitration of the 1899 Convention. ${ }^{32}$ Among others, as a result of the Second Peace Conference, one can refer to a declaration concerning obligatory arbitration in which, it was stated that:

while reserving to each of the Powers represented full liberty of action as regards voting, enables them to affirm the principles which they regard as unanimously admitted: It is unanimous:

1. In admitting the principle of obligatory arbitration.

2. In declaring that certain disputes, in particular those relating to the interpretation and application of the provisions of international agreements, may be submitted to compulsory arbitration without any restriction.

Rather interesting is that the document goes on by saying that the Conference was '... unanimous in proclaiming that, although it has not

30 Amos S. Hershey, 'Convention for the Peaceful Adjustment of International Differences' (1908), 2, AJIL, 29, 30.

31 See Report to the Conference from the First Commission on the Revision of the Convention of 1899 for the Pacific Settlement of International Disputes. See Rosenne (2001) 223-399.

32 The Convention for the Pacific Settlement of International Disputes prepared in 1899 was amended and enlarged, especially with regards to the commissions of inquiry, and a new chapter was added for facilitating appeal to arbitration by summary procedure. On the amendments regarding arbitration see Table 1.1 below. 
yet been found feasible to conclude a Convention in this sense, nevertheless the divergences of opinion which have come to light have not exceeded the bounds of judicial controversy ...'33

The negotiations at the Second Hague Peace Conference in 1907 about obligatory arbitration and about various categories of disputes to be subject thereto showed that the states agreed only in principle with obligatory arbitration in so far as it involved no concrete commitment and they were reluctant to assume any further concrete obligation already accepted at the First Peace Conference in 1899.

Notwithstanding, one could say that the Second Hague Peace Conference was a success and in the final analysis, an important step towards the introduction of general international arbitration had been made. Most experts were of the opinion that it was possible for the general introduction of obligatory arbitration to be achieved only gradually and that the peace conferences had made a considerable step to reaching that goal. ${ }^{34}$

33 Final Act of the Second International Peace Conference, 1907. See Rosenne (2001), 411.

34 While discussing the development of international arbitration and the judicial settlement of international disputes one should mention also the Central American Court of Justice, established by five Central American states (Costa Rica, El Salvador, Guatemala, Honduras and Nicaragua) which functioned between 1907 and 1917. The Court had jurisdiction not only for interstate disputes, but over certain cases of international character between a government and an individual who was a national of another state. During its existence of ten years, ten cases came before the Court, of which five cases were brought by individuals. According to many authors it was 'a matter of regret that this experiment in the administration international justice was so short-lived, and that the convention of 1907 was not revised and renewed in 1917'. On the Central American Court of Justice, see Manley O. Hudson, 'The Central American Court of Justice' (1932) 26, AJIL, 759, 785. 


\section{Table 1.1 Relevant provisions of the two Hague Conventions for the Pacific Settlement of International Disputes}

Convention of 29 July 1899

Title IV. International Arbitration

Chapter I. The System of Arbitration

Art. 15

'International Arbitration has for its object the settlement of differences between States by judges of their own choice, and on the basis of respect for law.'

\section{Art. 16}

'In questions of a legal nature, and especially in the interpretation or application of International Conventions, arbitration is recognized by the Signatory Powers as the most effective, and at the same time, the most equitable, means of settling disputes which diplomacy has failed to settle.'

\section{Art. 17}

'The Arbitration Convention is concluded for questions already existing or for questions which may arise eventually.

It may embrace any dispute or only disputes of a certain category.'

\section{Art. 18}

'The Arbitration Convention implies the engagement to submit loyally to the Award.'

\section{Art. 19}

'Independently of general or private Treaties expressly stipulating recourse to arbitration as obligatory on the Signatory Powers, these Powers reserve to themselves the right of concluding, either before the ratification of the present Act or later, new Agreements, general or private, with a view to extending obligatory arbitration to all cases which they may consider it possible to submit to it.'
Convention of 18 October 1907

Part IV. International Arbitration

Chapter I. The System of Arbitration

Art. 37

'International arbitration has for its object the settlement of disputes between States by Judges of their own choice and on the basis of respect for law.

Recourse to arbitration implies an engagement to submit in good faith to the Award.'

Art. 38

'In questions of a legal nature, and especially in the interpretation or application of International Conventions, arbitration is recognized by the Contracting Powers as the most effective, and, at the same time, the most equitable means of settling disputes which diplomacy has failed to settle.

Consequently, it would be desirable that, in disputes about the above-mentioned questions, the Contracting Powers should, if the case arose, have recourse to arbitration, in so far as circumstances permit.'

Art. 39

'The Arbitration Convention is concluded for questions already existing or for questions which may arise eventually.

It may embrace any dispute or only disputes of a certain category.'

Art. 40

'Independently of general or private Treaties expressly stipulating recourse to arbitration as obligatory on the Contracting Powers, the said Powers reserve to themselves the right of concluding new Agreements, general or particular, with a view to extending obligatory arbitration to all cases which they may consider possible to submit to it.' 